\title{
A WELL-KNOWN BUT PREVIOUSLY MISIDENTIFIED ODONTOGLOSSUM (ORCHIDACEAE: ONCIDIINAE) FROM ECUADOR
}

\author{
STIG DALSTRÖM \\ 2304 Ringling Boulevard, unit 119, Sarasota FL 34237, U.S.A. \\ Lankester Botanical Garden, University of Costa Rica, Cartago, Costa Rica \\ and National Biodiversity Centre, Serbithang, Bhutan \\ stigdalstrom@juno.com
}

\begin{abstract}
A previously misidentified species of Odontoglossum (Orchidaceae, Oncidiinae), from the botanically well explored western slopes of mount Pichincha in Ecuador is described and illustrated, and compared with similar species. The new species is most similar to $O$. cristatum, but differs in a larger plant habit with larger flowers that present a longer and straighter column with bifurcate wings, versus a more slender and more curved column with triangular, falcate column wings of $O$. cristatum.
\end{abstract}

Key words: Orchidaceae, Oncidiinae, Odontoglossum, new species, Pichincha, Ecuador, taxonomy

The genus Odontoglossum Kunth, (treated by some authors as Oncidium) consists of some of the most stunningly beautiful orchids that exist, and that have appealed to, and mesmerized not only orchid people around the world for almost two centuries. Odontoglossum species are also some of the most difficult to define taxonomically due to a variety of reasons. Their' impressive natural variation and floral plasticity may be the very reason why they are so attractive to growers but also turn taxonomy into a serious befuddlement. The species described here has been known to orchid collectors and growers for a long time but hiding under a different name, "Odontoglossum cristatum" (e.g. Bockemühl 1989: 56-58). Although our new species resembles the true $O$. cristatum Lindl., and a couple of other similar species in several aspects, it can be distinguished by a unique combination of features. Each feature may be shared by one or several other species but not in the same combination.

Odontoglossum furcatum Dalström, sp. nov.

TYPE: Ecuador. Pichincha: Near Tandapi, at $1800 \mathrm{~m}$, Oct. 1982. A. Hirtz 368 (holotype, SEL). FIG. 1, 2, 3C, $2 \mathrm{C} 1$.

DiAgnosis: Odontoglossum furcatum is most similar to O. cristatum Lindl. (Fig. 3A, 3A1, 4), which occurs further to the south in Ecuador, near the towns of Zaruma and Paccha at a similarly low elevation (1200-
$1500 \mathrm{~m}$ ), but differs in a larger plant habit with larger flowers that present a longer and straighter column with the typical bifurcated wings, versus a more slender and more curved column with triangular, shark-fin shaped, falcate column wings of $O$. cristatum. Odontoglossum hallii Lindl. (Fig 3D, 3D1, 5), has similar bifurcate column wings but occurs at much higher elevations, generally around 2800-3200 m, and exhibits larger flowers with a much broader, often pandurate, deeply lacerate lip. Odontoglossum cristatellum Rchb.f. (Fig. 3B, 3B1, 6), also exists at a higher elevation, generally between $2500-3000 \mathrm{~m}$, and has a shorter and stouter column with broad, usually rectangular wings.

Epiphytic herb.Pseudobulbs caespitose, ancipitous, slightly compressed, glossy, ovoid, bifoliate, $c a$. $7.0 \times$ $2.5-3.0 \mathrm{~cm}$, surrounded basally by 7 to 9 distichous sheaths, the uppermost foliaceous. Leaves subpetiolate, conduplicate, narrowly obovate to elliptic, acuminate, $20.0-28.0 \times 1.8-2.0 \mathrm{~cm}$. Inflorescences axillary from the base of the uppermost sheaths, suberect and arching to subpendent, to $c a$. $45 \mathrm{~cm}$ long, weakly flexuous to almost straight, to $c a$. 10 flowered racemes. Floral bracts appressed and scale-like, 5-15 mm long. Pedicel and ovary $20-30 \mathrm{~mm}$ long. Flowers relatively large, stellate to slightly campanulate, showy and scented but not overly pleasantly; dorsal sepal pale yellow with brown spots and markings, ovate to elliptic, slightly obliquely acuminate, entire, $40-45 \times$ 12-14 mm; lateral sepals similar in color, unguiculate, 

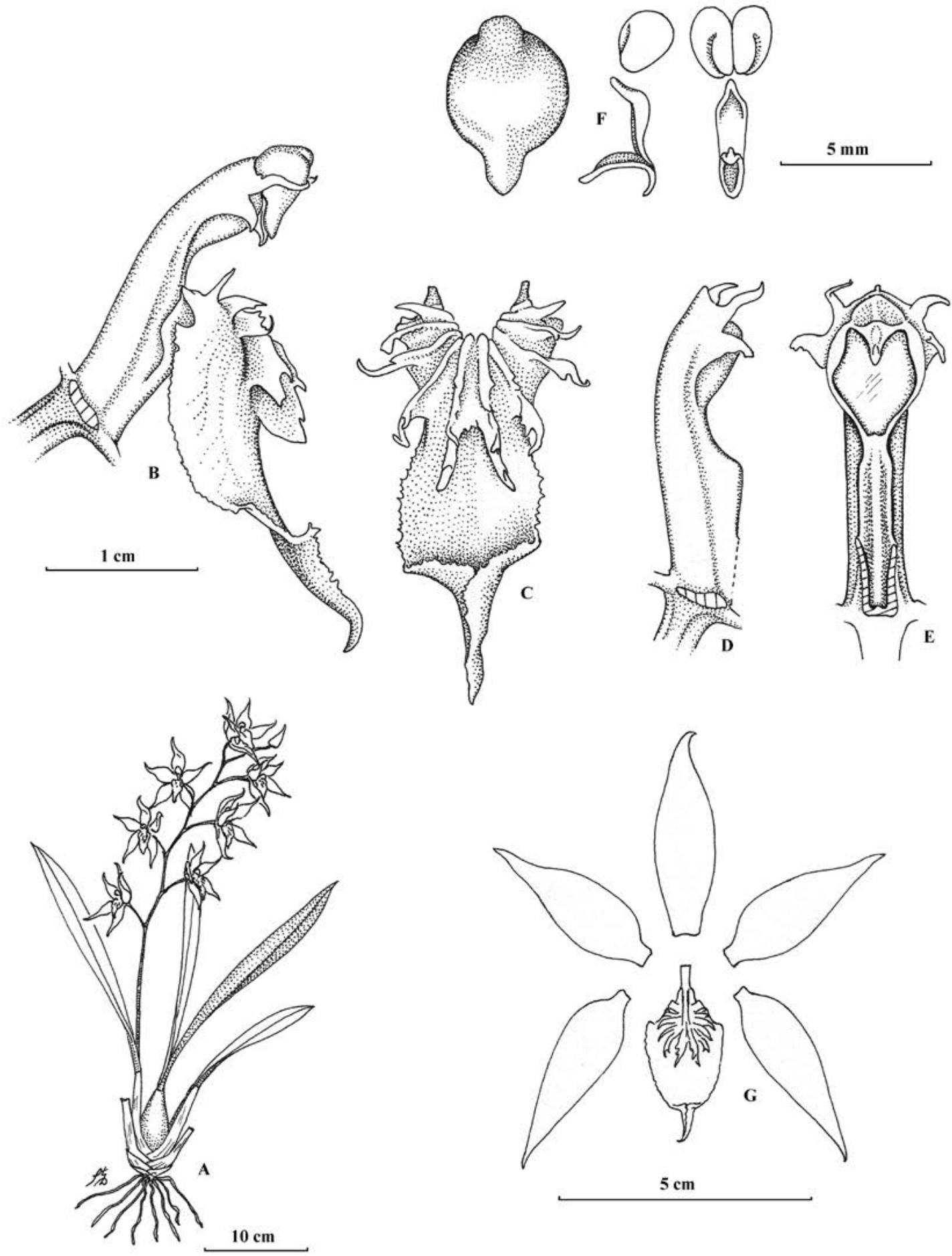

FiguRE 1. Odontoglossum furcatum. A. Plant habit. B. Column and lip lateral view. C. Lip front view. D. Column lateral view. E. Column ventral view. F. Anthercap and pollinia dorsal, lateral and back view. G. Flower dissected. Drawn from holotype by Stig Dalström. 


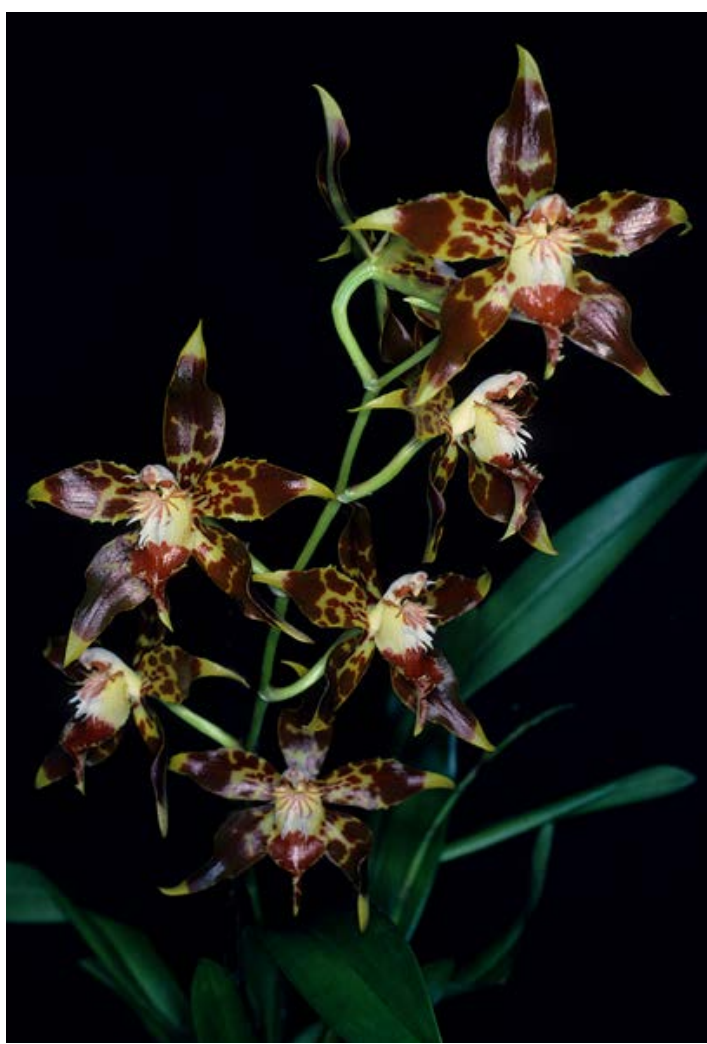

FIGURE 2. Odontoglossum furcatum, inflorescence from the plant that served as the holotype. Photo by S. Dalström.

obliquely ovate, acuminate, entire, $c a .40 \times 12 \mathrm{~mm}$; petals similar in color, unguiculate, obliquely ovate, acuminate, entire, $c a .40 \times 14 \mathrm{~mm}$; lip similar in color, attached to the basal and lateral flanks of the column for $c a .4 \mathrm{~mm}$, then free via a flat and narrow strap-like, $c a$. $2 \mathrm{~mm}$ long claw, then widening into short erect lateral lobes, then distinctly angled downwards into a large, cordate to broadly ovate, slightly crenulate or serrate, obtuse, apically convolute and acuminate lip lamina, ca. $35 \times 16-17 \mathrm{~mm}$; callus white to pale yellow with red-brown longitudinal stripes and spots, consisting of evenly spreading laterally flattened, fleshy keels, becoming larger towards the center and with additional uneven dorsal angles and fleshy tendrils; column white with some brown markings apically, erect, elongate, slightly curved downwards towards the apex, with lateral keels emerging basally and extending to, and angled just beneath the stigma, and with generally distinct and slightly variable bifurcate apical wings, ca. $20 \mathrm{~mm}$ long; anthercap campanulate rostrate with a dorsal lobule; pollinarium of two cleft/folded pyriform pollinia on an elongate rectangular, apically obtuse $c a$. 3.5-4.0 mm long stipe, on a conspicuously hooked pulvinate viscidium.

Paratypes: Ecuador. Carchi: Maldonado, $1800 \mathrm{~m}$, without date, A. Andreetta 0230 (SEL). Pichincha: Andes of Quito, ca. $2300 \mathrm{~m}$, August without date, W. Jameson 35 (K). Mt. Pichincha, 4100-4500 $\mathrm{m}[? ;$ improbable altitude-probably feet], 17 Aug. 1923, A. S. Hitchkock 21934 (US). Above Tandapi, 1550 m, 14 Mar. 1982, S. Dalström 161 (SEL). Km 80 along road Quito-Santo Domingo, 1500 m, 27 Sept. 1980, C. H. Dodson et al. 10557 (MO, RPSC, SEL). Same area, 1800 m, 20 June 1985, C. H. \& T. Dodson 15855 (MO). Tandayapa, road Nono-Nanegal, $2000 \mathrm{~m}$, collected and flowered in cultivation by A. Andreetta, 25 Feb. 1982, C. H. Dodson 12859 (SEL). Ca $6 \mathrm{~km} \mathrm{SE} \mathrm{of} \mathrm{Nanegal,} 2000$ m, 6 Sept. 1993, G. L. Webster et al. 30382 (UC-Davis). Mindo, collected Dec. 1992 and flowered in cultivation by J. Sönnemark in 1993 without date, S. Dalström 2065 (SEL). Imbabura: Above Garcia Moreno, $1800 \mathrm{~m}$, collected and flowered in cultivation by J. Sönnemark, Dec. 1992, S. Dalström et al. 2070 (SEL). Cotopaxi: Pujilí, Reserva Ecológica Los Illinizas, sector 11, sector Chuspitambo, W of Choasilli, 058'42" S, 7906'22'W, 1760 m, 3 Aug. 2003, P. Silverstone-Sopkin et al. 9736 (CUVC, SEL). La Maná, Reserva Ecológica Los Illinizas, sector El Oriente, access from Carmela, 040'18'S, 7804'45"W, $1572 \mathrm{~m}$, 14 July 2003, P. Silverstone-Sopkin et al. 9155 (CUVC, SEL).

Distribution: Northwestern slopes of the Andes in Ecuador, at 1500-2300 m.

Etymology: The name refers to the furcated (forked) column wings.

The earliest examined documentation of Odontoglossum furcatum is a nineteenth century collection by William Jameson from the "Andes of Quito", deposited at Kew. It shows a compact plant with a short inflorescence carrying two flowers and one bud, mounted between two specimens of $O$. hallii. This $O$. furcatum specimen was determined as "Odontoglossum cristatum" by Bockemühl in 1985. Indeed, these two species are closely related and resemble each other in several ways. The type of $O$. cristatum was collected by Theodore Hartweg in southern Ecuador near the town of Paccha, perhaps contemporary with the Jameson collection, and it has been observed in recent years by Dalström, growing at 1200-1500 m, an uncommonly 


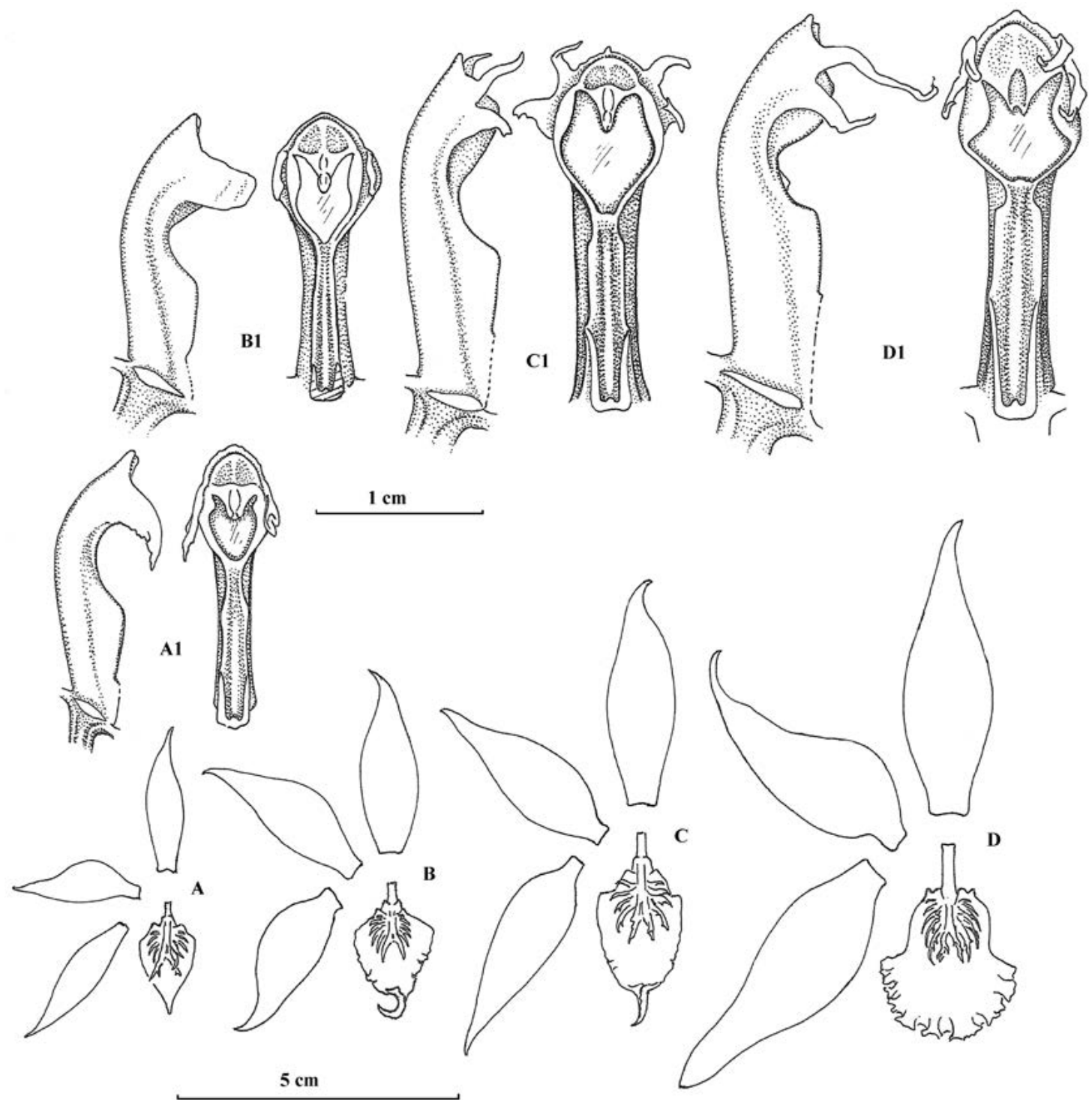

FiguRe 3. A. Odontoglossum cristatum (C. Dodson 13168, SEL), flower dissected; A1. Column lateral and ventral views.

B. Odontoglossum cristatellum (S. Dalström 556, SEL), flower dissected; B1. Column lateral and ventral views. C. Odontoglossum furcatum (A. Hirtz 368, SEL), flower dissected; C1. Column lateral and ventral views. D. Odontoglossum hallii (S. Dalström 650, SEL), flower dissected; D1. Column lateral and ventral views. Drawn by Stig Dalström.

low altitude for the genus. The flowers of $O$. cristatum are smaller in general and the column more slender and with differently shaped wings than $O$. furcatum. Although some natural variation occur in both species and occasional plants have been found that resemble intermediate forms, plants displaying the typical morphology of $O$. cristatum are not sympatric with $O$. furcatum. The bifurcate column wings of $O$. furcatum strongly resemble the wings of $O$. halli, which is a higher elevation species that displays larger flowers with a very different looking lip that easily separates the two taxa. Odontoglossum cristatellum may superficially resemble $O$. furcatum but is distinguished by the stout column with broad, generally rectangle column wings. Occasionally $O$. cristatellum can have more triangular column wings, resembling those of $O$. 


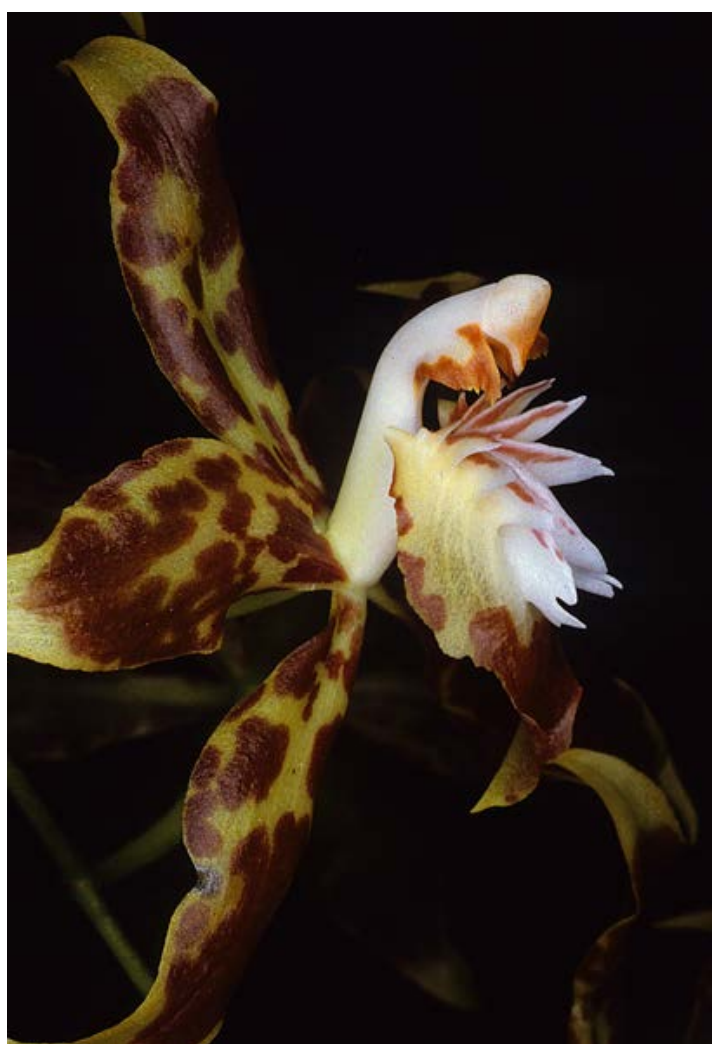

FIgURE 4. Odontoglossum cristatum. Ecuador. El Oro, $S$. Dalstrúom 962. Photograph by S. Dalström.

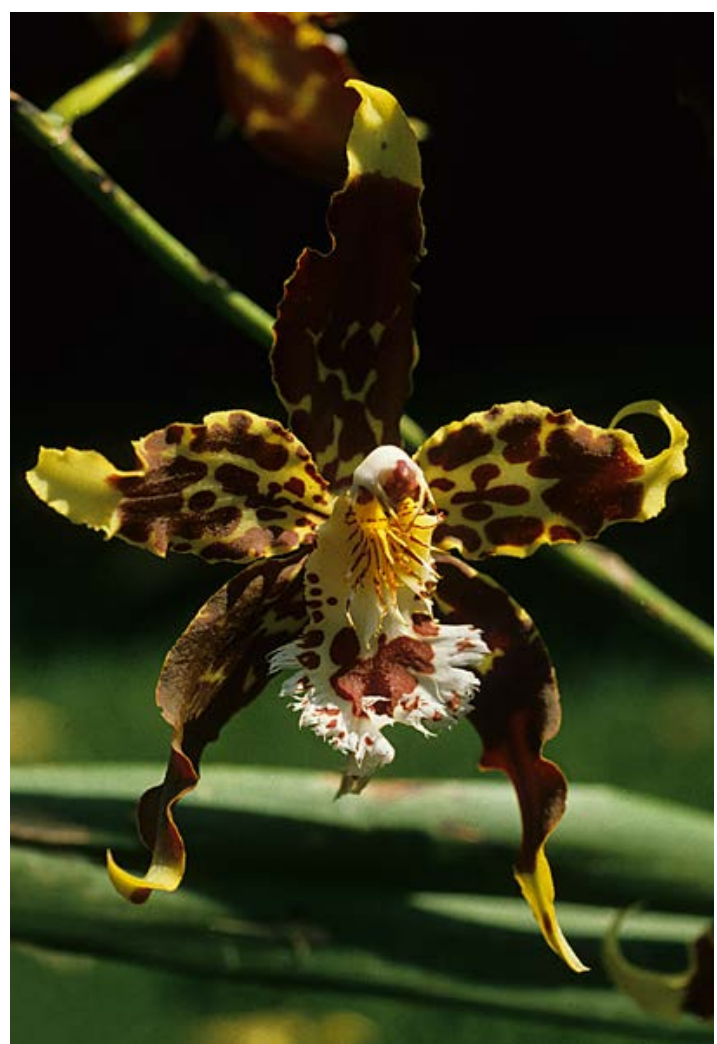

Figure 5. Odontoglossum hallii. Ecuador. Imbabura, S. Dalstrúom 738. Photograph by S. Dalström.

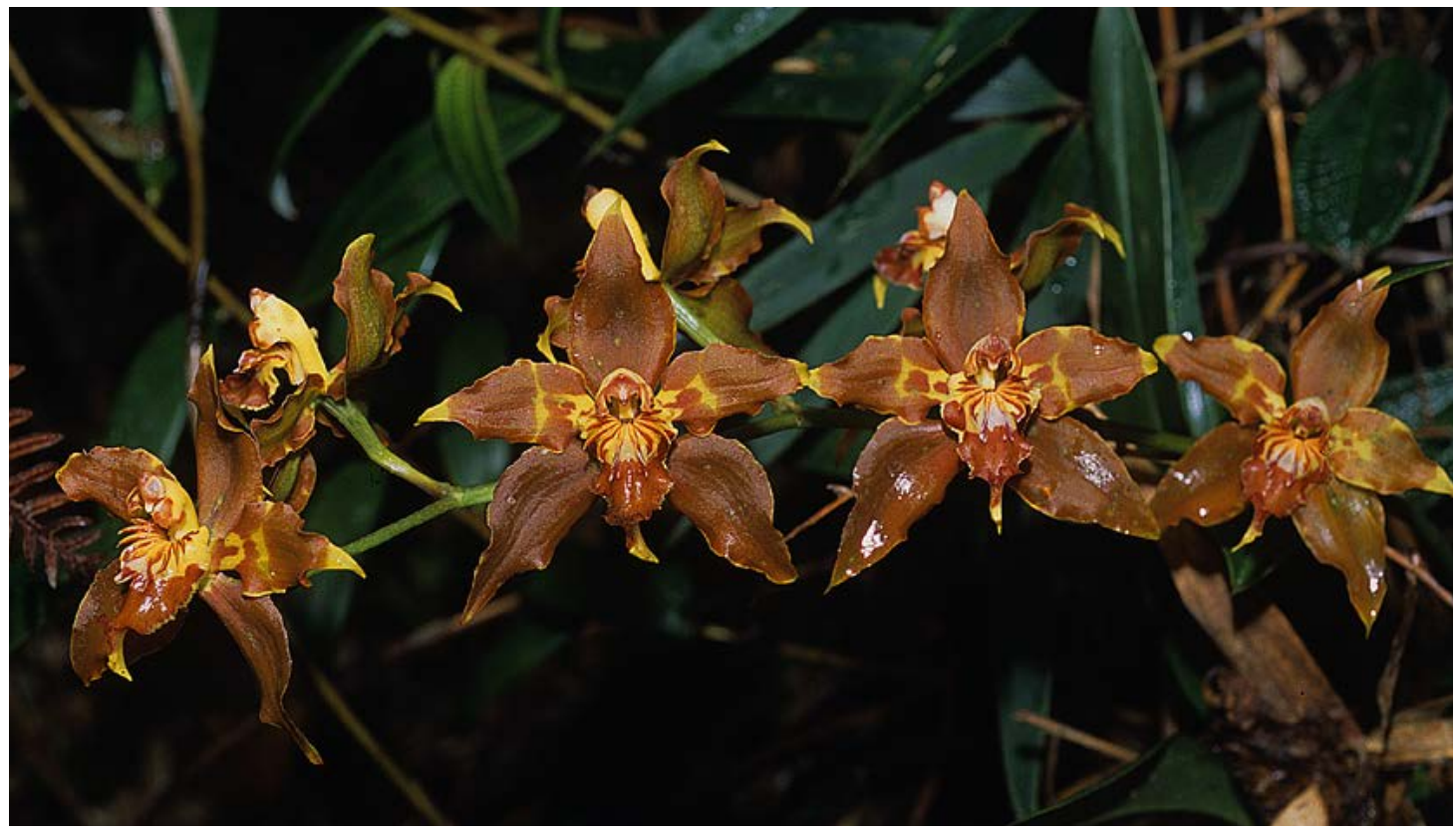

Figure 6. Odontoglossum cristatellum. Ecuador. Loja, S. Dalström 2772. Photograph by S. Dalström. 
cristatum and occasionally some intermediate forms are seen, possibly resulting from natural hybridization in areas where the two species occur in reasonably close proximity, a phenomenon often reported in Odontoglossum.
ACKNOWLEDGMent I wish to thank Wesley Higgins for viewing and commenting on the manuscript.

LiteRATURE CITED

Bockemühl, L. 1989. Odontoglossum, a monograph and iconograph. Brücke-Verlag Kurt Schmersow, Hildesheim, Germany. 